\title{
A CRISIS OF FAITH \& THE SCIENTIFIC FUTURE OF PATENT THEORY
}

\author{
OSKAR LIIVAK ${ }^{\dagger}$
}

\section{INTRODUCTION}

Throughout history, utilitarian rationales have formed the core foundation on which the United States patent system is built. Yet, more than ever before, that foundation appears untenably shaky. In 1958, the Senate hoped to gauge the performance of the patent system. It tasked economist Fritz Machlup with providing a comprehensive cost-benefit analysis of it. Machlup undertook the project, filed the report, and concluded with his now-famous assessment:

If we did not have a patent system, it would be irresponsible, on the basis of our present knowledge of its economic consequences, to recommend instituting [it]. But since we have had [one] for a long time, it would be irresponsible, on the basis of our present knowledge, to recommend abolishing it. ${ }^{1}$

Such indeterminate support surely caused concern but then again, at least at that time, perhaps we just had not developed the sophistication to make a full assessment. Indeed, as late as 1986, George Priest lamented that "[t]he ratio of empirical demonstration to assumption in [patent] literature must be very close to zero." Maybe it was okay if the jury was out on the patent system because maybe the data was still out, too.

† Professor of Law, Cornell Law School. (C) 2016 Oskar Liivak. For valuable comments and suggestions, the author thanks Jeremy Sheff and the participants of the St. John's Intellectual Property Law Center's symposium on Values, Questions, and Methods in Intellectual Property.

${ }^{1}$ See Subcomm. On Patents, Trademarks, and Copyrights of the Senate COMM. ON THE JUDICIARY, 85TH CONG., AN ECONOMIC REVIEW OF THE PATENT SYSTEM 80 (Comm. Print 1958) (review written by Fritz Machlup) [hereinafter ECONOMIC REVIEW OF PATENT SYSTEM].

${ }^{2}$ George L. Priest, What Economists Can Tell Lawyers About Intellectual Property: Comment on Cheung, in 8 RESEARCH IN LAW AND ECONOMICS: THE ECONOMICS OF PATENTS AND COPYRIGHTS 19 (John Palmer \& Richard O. Zerbe, Jr. eds., 1986). 
Today, thirty years after Priest made those comments, a lot has changed. ${ }^{3}$ Many researchers from law and from economics have made it their life's work to study and empirically measure the patent system. ${ }^{4}$ Yet, despite that outpouring of effort, the overall picture is, as put by Mark Lemley, "complicated." $\mathrm{We}$ still have no proof that definitively refutes or supports the system, and we are still just "muddl[ing] through." 6 But now, with all that effort expended, the ambivalence cannot be ignored. What was once a nagging concern is now an inescapable alarm.

What to do and where to turn during a crisis is never easy. Assessing our options certainly seems prudent. In his book Justifying Intellectual Property, Robert Merges does just that. He opens the book explaining, "Every time I ... go looking for the utilitarian footings of the field, I come up empty." Rather than drop support for intelletual property altogether, Merges leaves behind its traditional utilitarian roots and instead aims to understand and justify intellectual property as a "fundamental right" as understood by Rawls, Waldron, Locke, and Kant. ${ }^{8}$ In many ways, the book is his reaction to the current utilitarian impasse. As he had been a scholar who often employed law and economics rationales, that new, decidedly nonutilitarian focus was surprising, and apparently it was surprising even to Merges himself. $^{9}$

In part in reaction to Merges's comments, Mark Lemley published a recent essay decrying any abandonment of utilitarian foundations for intellectual property. ${ }^{10}$ His essay has provoked something of a minor firestorm in the usually placid world of intellectual property scholars. ${ }^{11}$ Lemley's primary concern with the shift from utilitarian arguments to more

${ }^{3}$ Mark A. Lemley, Faith-Based Intellectual Property, 62 UCLA L. REV. 1328, 1332 (2015) ("In the past three decades there has been an unprecedented-indeed, astonishing-outpouring of sophisticated empirical work on virtually every aspect of IP law and innovative and creative markets.").

${ }^{4}$ See id.

5 Id. at 1334.

6 See ECONOMIC Review of Patent System, supra note 1, at 80.

7 ROBERT P. MERGES, JUSTIFYING INTELLECTUAL PROPERTY 3 (2011).

8 Id.

9 Id. at 4.

${ }^{10}$ See generally Lemley, supra note 3.

11 See Lisa Larrimore Ouellette, Lemley on Faith-Based IP (Apr. 2, 2015), http://writtendescription.blogspot.com/2015/04/lemley-on-faith-based-ip.html (cataloging the responses to the essay). 
fundamental rights is the lack of any limiting principles that will produce a balanced compromise between disparate competing interests. ${ }^{12}$ For him:

A utilitarian IP framework has a metric for deciding whether we should give control over those terms to the people who claim them. But if IP is a Right, granted to the first creator not for a purpose but simply because they are first, it is hard to find a similar limiting principle. ${ }^{13}$

Furthermore, Lemley supports utilitarian foundations over a rights-based system because a rights-based approach is "not a science[;] ... it does not admit the prospect of being proven wrong." ${ }^{4}$ He added that he is trying to draw the line "between theories of IP that are responsive to evidence and those that are impervious to it." 15

It is Lemley's call for a falsifiable, scientific utilitarian theory that is the focus of this Essay. I wholeheartedly agree that we should endeavor to provide such a utilitarian theory for the patent system. But this Essay argues that this call is more radical than it appears. If we want a proof-based system around which consensus could grow, then we have to abandon the incentive-focused, regulatory model that is today's standard. That theory is based on an "intractable cost-benefit analysis that resists either justification or, alternatively, falsification." ${ }^{\text {"6 }}$ Although clad in the trappings of a cost-benefit analysis, the theory has no hope of ever being determinate, and accordingly, it should be jettisoned. Try as we might, the framing of the patent system as a market-skewing intervention inherently precludes the theory from achieving the sought after falsifiability.

12 But see MERGES, supra note 7, at 159 (dedicating a significant portion of his book to a central "Proportionality Principle" that puts bounds on intellectual property and prevents "excessive" leverage).

${ }_{13}$ See Lemley, supra note 3, at 1341. Though not the focus here, I disagree that such nonutilitarian thinking leads inexorably to the ever increasing reach of intellectual property. Elsewhere I have argued-along with my co-author Eduardo Peñalver-that arguments based on autonomy, personhood, and efficiency all provide limits for intellectual property. See generally Oskar Liivak \& Eduardo Peñalver, The Right Not to Use in Property and Patent Law, 98 CORNELL L. REV. 1437 (2013).

${ }_{14}$ Lemley, supra note 3 , at 1346.

${ }^{15} I d$. at 1345.

${ }^{16}$ Oskar Liivak, Establishing an Island of Patent Sanity, 78 BROOK. L. REV. 1335, 1337 (2013) [hereinafter Liivak, Establishing an Island of Patent Sanity]. 
Unsettling as this is, this failure of proof for the current patent theory should not surprise us. Actually, we should be surprised that we ever thought our current theory could be justified. The fact is that we picked a pathologically defective framing for our patent system. As is conventionally understood today, the system is seen as exclusive rights that aim to reward inventors so that they are "artificially" drawn into the world of inventing. ${ }^{17}$ Patents are seen as a government mediated reward to induce optimal amounts of inventive activity and that reward is funded by taxing those that infringe the patent rights. This is a foundational notion that, if noted at all anymore, is seen as surely correct and uncontroverted.

But the current reward via exclusion framing is deeply problematic. Once we start down that road, where the very purpose is to distort private decision making, we have sealed our fate and we are heading for unresolvable indeterminism. Our inability to prove or disprove the utilitarian balance for such a system was preordained by our framing. With "artificial" inducement as the stated goal, important utilitarian metrics are taken off the table. The price system is not available to measure and justify the patent system because we have purposefully distorted it. It is no wonder that patent controversy has not been resolved and that we are at best still just "muddl[ing] through." ${ }^{18}$

This Essay takes aim at this inducement framing, and it lays bare its pathologies, explaining that, by inducing invention, we will not be able to make any meaningful assessments of the costs and benefits of the system. There is no doubt that the business of invention and innovation is complex, but by framing patents as inducement we have made that job near impossible.

There are several fatal flaws with this understanding. First, on a macroeconomic level, the inducement system requires knowing how much invention or innovation society wants. Certainly, most agree that we want some positive amount of innovation, but beyond that, it is anyone's guess. The designers of an inducement-focused patent system need to know-at least on a macro level-the optimal amount, but nobody has that information. When someone is drawn away from otherwise productive activity by the lure of the patent, how much has

17 DAN L. BURK \& MARK A. LemLeY, THE PATENT CRISIS AND HOW COURTS CAN SOLVE IT 8 (2009).

18 See ECONOMIC Review of Patent System, supra note 1, at 80. 
society lost? ${ }^{19}$ This design parameter is different in kind from those needed in the rest of the economy. A central advantage of the private property market is that we need not know such relative allocations beforehand in designing the system. Instead, they result from decentralized decision making based on the price system. In short, inducement is generally not the central design feature elsewhere in the economy. Instead, the amount of activity in an industry is an output result of the neutral private property platform.

Second, even if the optimum level of innovation is not knowable ex ante, it perhaps could be identified through trial and error. By selecting a random positive level, then measuring the resulting costs and benefits, the level of innovation can be adjusted to optimize the net benefit by trial and error. But this is near impossible with the current inducement-framing system. We do not have the tools to measure the costs and benefits on a micro or macro level. Again, because the pricing of patent transactions is no longer tied to alternate uses of scarce resources, the costs and benefits of this system cannot be calculated. The system as a whole remains without solid footing.

Third and lastly, though the overall balance is near impossible to calculate, reward framing appears to involve real costs without guaranteeing any real benefits. First, there is the deadweight loss. Reward framing often leads to a fixation on exclusion. It is thought that a proper patent reward generally must exclude some from using the invention. Otherwise, the patentee could not receive his proper reward. This limit on access is the cost side of the famous incentive-versus-access compromise that is at the core of intellectual property debates. Excluding others is seen as necessary yet it also condemns the system to incurring at least this deadweight cost.

In addition, this exclusion focus has its most pernicious impact on actual innovators. The patent system allows patentees to tax independent innovators even where the patentee has not engaged in any attempts to commercialize. In short, actual innovators are being taxed to provide tribute to patentees who are often not innovating. Much of the "troll problem" can be seen as aggresively leveraging this feature. With inducement

${ }_{19}$ See Arnold Plant, The Economic Theory Concerning Patents for Inventions, 1 ECONOMICA 30, 41-44 (1934) (arguing that a subsidy vision of patents has nonzero yet hard to quantify opportunity costs). 
framing, the dynamic costs are considerable. ${ }^{20}$ Innovation, where new inventions are actually utilized, does provide real societal benefits. But today's inducement framing never requires that patentees engage in any actual innovation. In fact, the incentives may be aligning against real innovators. Today, noninnovators are increasingly taxing actual innovators. This hardly seems like a system that can guarantee any societal benefits. We know this framing is incurring real costs to society, but we cannot be confident about any benefits.

So if inducement inherently introduces so many problems, is it necessary? Is inducement the only way to frame the patent system? This Essay argues, no, we do not need to induce and we should not want to. There are other theories for the patent system that do not fall prey to the same pathologies. Though the goal still should be to "promote the [p]rogress of [s]cience and useful [a]rts," ${ }^{21}$ we need not fulfill that goal by directly subsidizing invention. Rather, a patent system should remain agnostic as to participation. It should not try to induce people to invent or innovate. Instead, the patent system should be a neutral platform that is available for inventors to sell their wares-that is, their inventions-to technology users. When someone decides that the best use of his or her time is to invent and sell the technology to others, then this platform should be available for them. This allows private decision making to guide participation. The system should be available to support those that decide that they can create and sell a new invention to enough people that the cumulative revenue makes inventing the best use of their time and resources. Likewise, the system should be available for technology consumers who decide to get new technology when the utility from using the new technology exceeds the value of the other things that could have been bought with the requested licensing fee. There are numerous advantages of building our understanding of the patent system around such a neutral technology transfer market. ${ }^{22}$

First, in this view, the patent system does not induce or subsidize. Professional inventors and technology users will employ the system when such an ex ante technological exchange

${ }^{20}$ See Kenneth W. Dam, The Economic Underpinnings of Patent Law, $23 \mathrm{~J}$. LEGAL STUD. 247, 262-63 (1994) (outlining the various costs of a patent system).

${ }^{21}$ U.S. CONST. art I, $\S 8$, cl. 8.

${ }^{22}$ See Liivak, Establishing an Island of Patent Sanity, supra note 16, at 1353. 
inherently benefits both parties. Importantly, because the system is not aiming to distort or subsidize, then the price system can operate to align private decision making with societal decision making. In other words, the system is designed so that private decision making aligns with society's cost-benefit analysis. Wherever a professional inventor can stay in business by selling his or her inventions to others, then society will concur that the creation and commercialization of that technology was the best use of that inventor's scarce resources. Importantly, because it is a neutral platform, the design of the system does not need to know the optimal amount of inventive activity ex ante. The resulting amount of inventive activity is an output of the system rather than a necessary initial input. We are not trying to artificially divert people to this system. Instead, they will participate when the best use of their time and scarce resources is inventing and innovating.

In addition, with a technology transfer focus, deadweight loss is a bug, rather than an unfortunate but necessary feature. In the current inducement-via-exclusion framing, deadweight loss is seen as an unfortunate but largely unavoidable feature. As famously put by Kenneth Arrow, "In a free enterprise economy, inventive activity is supported by using the invention to create property rights; precisely to the extent that it is successful, there is an underutilization of the information." With an innovation focus, a potential user without access to the technology is not an unfortunate, necessary feature, but rather a market failure that should be remedied.

The following aims to expand and detail these arguments. Part I provides the conventional incentive narrative for the patent system. It lays out the ambiguous support for that system and then it shows how that ambiguity derives in large part from its framing as a system of inducement. Part II takes the diagnosis from Part I and aims to build a patent system that avoids those pitfalls. It describes a neutral system of ex ante technology exchange. Importantly, such a system does not induce, but rather enables such technology transfers by regulating-and often prohibiting - the acts that would harm a business model based on technology creation and transfer.

${ }^{23}$ Kenneth J. Arrow, Economic Welfare and the Allocation of Resources for Invention, in THE RATE AND DIRECTION OF INVENTIVE ACTIVITY: ECONOMIC AND SOCIAL FACTORS 609, 617 (Nat'l Bureau of Econ. Research ed., 1962). 


\section{INDUCEMENT AND ITS PATHOLOGIES}

This Part outlines the conventional inducement framing of the patent system, then enumerates three of its major deficiencies. First, the inducement narrative necessarily involves determining ex ante the optimal amount of innovative activity and the reward that will induce that activity. The parameters for these critical functions are unknown. From the outset, this system is based on unknown variables. Second, even admitting that choosing an ex ante level of reward is guesswork, the conventional framing precludes any cost-benefit assessment that might allow a trial and error search that could converge toward an optimum amount of innovative activity. Lastly, the inducement framing is fixated on exclusion. Though no one celebrates excluding others as being desirable, the reward framing sees exclusion as the necessary-and even tragic-price for providing the incentives that induce.

\section{A. The Conventional Inducement Narrative}

Most policy justifications for the patent system begin by noting that the informational goods at the heart of the patent system are inherently different than tangible goods. Once created, an informational good can be copied rather easily. ${ }^{24}$ This makes creation and sale of such goods complicated. Every purchaser of the good can turn around to become a competitor. Without some kind of regulation, copying and reselling-that is, piracy-is too attractive. The worry is that, in such a world, too few will risk investing scarce resources in such a tenuous business model. As a result, "[i]f we [do not] do something...everyone will want to be an imitator, not an inventor." ${ }^{25}$

${ }^{24}$ This has been emphasized for some time now. See, e.g., Letter from Thomas Jefferson, President, U.S., to Isaac McPherson (Aug. 13, 1813) ("[The] peculiar character [of an idea] is that no one possesses the less, because every other possesses the whole of it. He who receives an idea from me, receives instruction himself without lessening mine; as he who lights his taper at mine, receives light without darkening me. That ideas should freely spread ... seems to have been peculiarly and benevolently designed by nature ....").

${ }^{25}$ BURK \& LEMLEY, supra note 17 , at 7-8. 
From those correct observations, though, the argument moves quickly to the assertion that society must affirmatively "encourage invention by rewarding inventors." 26 The patent system is seen as "deliberate government interventions in the market-a sort of mercantilist economic policy for artificially stimulating innovation."27 The reward aims to induce people to invent. Patents give out "above-market rewards to creators of certain works that would not be created, or not created as soon or as well, in the absence of reward." 28 Within this discourse there is debate surrounding what activities are to be rewarded and what institutions are best situated to grant and manage the reward, but the notion of inducing via a monetary reward is surely agreed upon.

As to processes for administering the reward, there are a number of choices. A reward to inventors could be administered through a prize system, a grant system, a tax break system, or an exclusive rights system. There is long-standing discourse on the comparative advantages of these different modes. ${ }^{29}$ The United States Constitution specifically enumerates that Congress should promote progress via "exclusive $[\mathrm{r}] \mathrm{ight}[\mathrm{s}],{ }^{\text {"30 }}$ thus, much of the discourse has largely remained focused on patents and their exclusive rights. In recent years, there has been a notable renaissance exploring these alternatives. ${ }^{31}$

In a prize system, a prize amount is chosen to induce the optimal amount of innovative activity. As argued below, it is generally unknown how much innovative activity is optimal or how much reward is needed to induce that activity for a rewardfocused patent system, and the administration is slightly different. The system still needs to determine the optimal level of activity that the system aims to induce. Rather than turning to the general treasury to fund the prize, the patent system funds the patent reward by granting valuable rights of exclusion to the

${ }^{26} I d$. at 8.

27 Id.

28 MERGES, supra note 7, at 2.

${ }^{29}$ See, e.g., Brian D. Wright, The Economics of Invention Incentives: Patents, Prizes, and Research Contracts, 83 AM. ECON. REV. 691, 691 (1983); see also Fritz Machlup \& Edith Penrose, The Patent Controversy in the Nineteenth Century, $10 \mathrm{~J}$. ECON. HIST. 1, 10-11, 19-20 (1950).

${ }^{30}$ U.S. CONST. art. I, $\S 8$, cl. 8.

31 See Daniel J. Hemel \& Lisa Larrimore Ouellette, Beyond the Patents-Prizes Debate, 92 TEX. L. REV. 303, 304-05 (2013). 
patentee. With these, the patentee taxes those that infringe on the rights granted by the patent. The patentee "is thus 'akin to a private attorney general' who, aided by the courts, goes forth and scours the countryside collecting from infringers the tax that is owed to him." 32

One advantage of this exclusionary prize system is that the prize is adjusted automatically. Because the reward is realized by taxing those who infringe the patented technology, the reward varies based on the popularity and relevance of the patented technology. If a patent covers important technology that many want access to, then the patentee can recover a large reward via patent exclusion. If the technology has no adherents or is of no value, that will be reflected in its reward. This feature allows the patent system to be a reward system wherein the reward is not fixed beforehand to a set amount. The doctrine of claim's scope allows the system to reward patentees with larger prizes that correspond to the merits of the "real contribution" of the inventor.

There is considerable debate over the exact acts that need to be promoted, as well as what institution is best suited to do the promoting. Despite the diversity of opinion, they have more in common than is often admitted. For example, though an exclusive rights system and a prize system surely have differences in detailed implementation, they are both, at their core, reward systems that aim to induce innovation and invention. They both subsidize and thereby induce people to engage in technological progress. The difference lies in how the promised subsidy is defined and how the reward can be collected.

But even when we focus on inducement via exclusionary rights, there is still a further debate over what particular acts should be promoted. Generally, inventors and innovators aim to advance science and technology. But within that broad area, details are often murky and terms are used with imprecision. The buzzwords of invention and innovation are often bandied about interchangeably, but there are differences between the two. As used here, invention relates to the act of conceiving a technological solution to a particular problem. Discovering a solution is certainly a positive step but achieving societal benefits

${ }^{32}$ Oskar Liivak, Private Law and the Future of Patents, HARV. J.L. \& TECH (forthcoming 2017) (quoting Ted Sichelman, Purging Patent Law of "Private Law" Remedies, 92 TEX. L. REV. 517, 532-33 (2014)). 
requires more than conceiving a solution alone. ${ }^{33}$ In general, society benefits only when a technological solution is put into practice. If someone conceives of a cheaper, better process to produce something, that is great from the standpoint of human knowledge, but real societal improvement only occurs when that knowledge is put into practice. That act, taking technology that has been invented and putting it into widespread practice, is innovation. ${ }^{34}$ The distinction between invention and innovation is relevant to the discussion of patent reward because there are ongoing disputes about the exact act that should be rewarded..$^{35}$

But even with the ongoing debates about what acts we are trying to induce via a reward, there is agreed-upon logic underlying these inducement framing of the patent theories. Without doing something to help inventors, the "normal" market will not consistently and regularly provide remuneration to inventors for their efforts. Being an inventor will just not pay the bills and fewer people will invent. The most obvious solution is to simply make inventing more profitable to make up for the shortfall.

In theory, the utilitarian accounting for this system is also straightforward. The benefits are netted against the cost with the hope that the results are positive. "The gains from this scheme, in the form of new works created, are weighed against social losses, typically in the form of the consumer welfare lost when embodiments of these works are sold at prices above the marginal cost of their production." ${ }^{36}$ But as described throughout this Essay, this task has proved to be quite hard in practice. ${ }^{37}$

${ }^{33}$ Of course, there can be positive social benefits just from coming up with a solution even before that solution is put in practice. Knowing that a problem has been solved can spur others to look for alternate solutions within the same general area. Furthermore, knowing how a problem was solved can spur others to apply the same rationale to some related area. These are both beneficial spillovers that could result simply from coming with a solution even before that technological solution is put into widespread practice.

${ }^{34}$ See JOSEPH A. SCHUMPETER, BUSINESS CYCLES: A THEORETICAL, HiSTORICAL, AND STATISTICAL ANALYSIS OF THE CAPITALIST PROCESS 85 (1939) (stating that invention alone without actual usage is "without importance to economic analysis").

${ }^{35}$ See Edmund W. Kitch, The Nature and Function of the Patent System, 20 J.L. ECON. 265, 268 (1977); F. Scott Kieff, Property Rights and Property Rules for Commercializing Inventions, 85 MINN. L. REV. 697, 703, 707 (2001); Mark A. Lemley, Ex Ante Versus Ex Post Justifications for Intellectual Property, 71 U. CHI. L. REV. 129, 131 (2004).

${ }^{36}$ MERGES, supra note 7 , at 2.

${ }^{37}$ See supra Introduction. 


\section{B. Pathologies of Inducement}

As argued by Hovenkamp and Bohannon, "finding the right balance [for intellectual property] has proven to be one of the most difficult questions that government policy has ever had to face." 38 So far, there is no evidence that we are converging on a solution to this challenge. Though this lack of justification is dispiriting, it should not be surprising. A reward-based exclusive rights system is pathologically defective. It aims to induce the optimal amount of innovative activity. And we are simply not equipped to design such a system. Though its utilitarian contours are easy to define in theory, in practice, we have been asking too much of ourselves. As noted by Merges, designing such a system is "impossibly complex."39 "Estimating costs and benefits [in this system] ... are all overwhelmingly complicated tasks." 40

Whether the reward is mediated directly or through an award of exclusive rights, at least at the macro level, such a system needs to set the optimal amount of innovative activity as an input to system design. But we just do not have the tools to determine how much innovative activity society needs. Surely it is a positive amount, but the exact positive amount is unknown. Importantly, these types of determinations are not made for other parts of the economy. Optimal amounts of activity devoted to various industries and particular endeavors are the end results of the private property-mediated market system. The system produces those natural outputs; they are not required as necessary informational parameters for system design. Even though directly rewarding inventors may well seem like the obvious way to implement a system "[t]o promote the [p]rogress of [s]cience and useful [a]rts," 41 that framing puts an unknowable parameter as a core design variable.

There are other related pathologies as well. It is conceivable that if the system allowed for adjustment, the optimal amount of innovative activity could be discovered by repeated trial and error. But this, too, is impossible as we lack the means to assess the costs and benefits of the system. Here, the pathology of the

${ }^{38}$ Christina BoHanNan \& Herbert HovenKamp, Creation without RESTRAINT: PROMOTING LIBERTY AND RIVALRY IN INNOVATION 404 (2012).

${ }^{39}$ MERGES, supra note 7, at 2.

${ }^{40}$ Id.

${ }^{41}$ U.S. CONST. art. I, § 8, cl. 8. 
reward framing again rears its ugly head. Elsewhere in the economy, critical decisions about how to use scarce resources are generally made in a decentralized fashion, guided primarily by the price system. ${ }^{42}$ Importantly, where the price system is working, those observable price signals and transactions are tied to the revealed consumer preferences for various uses of our collective scarce resources.

Such beneficial metrics are not available with an inducement-based patent system. They have been largely taken off the table because the inducement system specifically distorted them. Patents are trying to "artificially" inflate the value of inventing. In such a world, the prices that are paid for patent licenses bear no connection to a revealed preference between use of the technology and the alternate uses of scarce resources. Instead, as described above, a patent license is just part of a larger scheme whereby the patentee collects the patent reward by taxing individuals who knowingly or unwittingly infringe. Without a functioning price system, it is near impossible to measure either the costs or benefits of the system. The only area where headway has been made is in calculating the private costs of using the patent system by focusing on the legal fees associated with the patent system. ${ }^{43}$ These audits of the patent system are contested, but nonetheless, the existence of real numbers and debate is an improvement. Sadly, that represents but one aspect of the total costs and benefits of the patent system, and thus, a fuller accounting is just not possible. Much of the blame for that indeterminacy results from having framed the system as a reward to induce.

In addition to these pathologies, the standard reward framing puts an unnecessary and unfortunate focus on excluding others as the hallmark of a properly functioning system. In the

42 William J. Baumol \& Alan S. Blinder, Economics, Principles and POLICY 292 (11th ed. 2010) (" $[\mathrm{A}]$ market system uses prices to coordinate economic activity[, instead of centralized planning].").

${ }^{3}$ See James Bessen \& Michael Meurer, Patent FaIlure: How Judges, BUREAUCRATS, AND LAWYERS PUT INNOVATORS AT RISK 16 (2008) ("By almost any interpretation, the United States patent system could not be providing overall positive incentives for these United States public firms by the end of the 1990s. The risk of patent litigation that firms faced in their capacity as technology adopters simply outstripped the profits that they made by virtue of owning patents.... Moreover, preliminary data for more recent years suggest that this problem has gotten worse since 1999.”). 
conventional reward framing, the "natural" baseline for ideas has them freely shared with prices set to marginal cost-therefore close to zero. As famously put by Kenneth Arrow, "[A]ny information obtained, say a new method of production, should, from the welfare point of view, be available free of charge (apart from the cost of transmitting information). This insures optimal utilization of the information ...."44 Echoing Justice Brandeis's eloquent views, ideas should be "free as the air to common use."

With a price set at zero, ideas will be able to spread, and indeed, all can use the idea. Arrow, though, quickly interjects that despite the appeal of this utopic public domain, such a scheme would "provide[] no incentive for investment in research." ${ }^{\prime 6}$ No one would invest in producing ideas, because there would be no ability to recoup the costs. Arrow then suggests that a property rights system can fix this: "In a free enterprise economy, inventive activity is supported by using the invention to create property rights; precisely to the extent that it is successful, there is an underutilization of the information." ${ }^{37}$ Arrow's last statement gets at the core of the incentives versus access paradox. ${ }^{48}$ In essence, we need to block access so that price can be raised above marginal cost to ensure a positive incentive to initially create-or commercialize-the work; excluding some from use of the work is inefficient. At present, the use of valuable societal resources is not being maximized. This is the well-known, deadweight loss cost often discussed in intellectual property debates.

The first two pathologies of the inducement system addressed the lack of utilitarian tools for designing or assessing a reward-based patent system. The exclusion fixation of the reward theory is somewhat different but nonetheless still damaging to any prospect of a stable, accepted system. The reward via exclusion frame inherently leads to controversy because it necessarily incurs a real cost. No one celebrates the

${ }^{44}$ Arrow, supra note 23, at 616-17.

${ }^{45}$ Int'l News Serv. v. Associated Press, 248 U.S. 215, 250 (1918) (Brandeis, J., dissenting).

46 Arrow, supra note 23, at 617.

47 Id.

48 See Glynn S. Lunney, Jr., Reexamining Copyright's Incentives-Access Paradigm, 49 VAND. L. REV. 483, 486 n.5 (1996). 
exclusion of others from use of a productive idea, but the reward framing accepts this as an unfortunate but necessary feature of the system. ${ }^{49}$

\section{INNOVATION WITHOUT INDUCEMENT}

In his book, Merges eludes to some of the impossibility described above:

"[T]his complexity poses a major problem for utilitarian theory.

The sheer practical difficulty of measuring or approximating all the variables involved means that the utilitarian program will always be at best aspirational. Like designing a perfect socialist economy, the computational complexities of this philosophical project cast grave doubt on its fitness as a workable foundation for the field. ${ }^{350}$

I agree completely with Merges here but for one important detail. He argues that this problem dooms "utilitarian theory." I disagree. It dooms the particular framing that we have chosen. The above discussion focused on some key features of the conventional reward framing for the patent system. That reward system provides a perverse framing "that resists evaluation. We cannot establish the overall costs or benefits of the system. We cannot prove it is worth it, nor can we prove it is not. The system just endures in a persistent indeterminate state." W1 We have an unscientific system controlling a critical engine for economic growth. If Lemley is serious in moving patent theory toward a scientific footing, I hope he is ready to ditch that standard incentive framing as well. I think it is the only way we can hope to get there.

49 Some have pointed to the potential for price discrimination to help reduce these deadweight losses and, indeed, where it can be employed, price discrimination will help, but, where it cannot be used, the reward framing still accepts exclusion as the proper outcome. See F. Scott Kieff, Coordination, Property, and Intellectual Property: An Unconventional Approach to Anticompetitive Effects and Downstream Access, 56 EMORY L.J. 327, 390, 422 (2006). In other words, because price discrimination increases the share of surplus that goes to the patentee, patentees have incentives to deploy price discrimination where they are able. If they cannot deploy it effectively, then the reward framing accepts exclusion as the correct outcome.

50 MERGES, supra note 7, at 2-3.

${ }^{51}$ Oskar Liivak, Maturing Patent Theory from Industrial Policy to Intellectual Property, 86 TUL. L. REV. 1163, 1166 (2012) Thereinafter Liivak, Maturing Patent Theory]. 
As argued in this Essay, those problems stem rather directly from the framing. Once it is decided that the purpose of the patent system is to induce inventive activity by granting rewards of valuable exclusive rights, the indeterminacy is baked in. Rather than lament the quagmire, it should be surprising that this system could have ever been justified on utilitarian grounds. Given this dour assessment, perhaps the patent system should be abandoned, or at least the utilitarian arguments in support of it. Either would be an understandable reaction. Indeed, a number of patent scholars are exploring both of these options. But there is another possibility. Perhaps reward framing is not the only way to structure a utilitarian-justified patent system. And if there are alternatives, they should be explored. Moreover, as argued above, reward framing fails because it entails too many pathological features. That failing suggests exploring alternatives that lack these problematic characteristics.

A number of patent scholars have begun to work on a system that has promise in this regard. Rather than focusing on delivering a reward for invention, scholars have instead been framing the patent system as the legal infrastructure that enables technology creators to sell their creations to technology users. $^{52}$ A patent system based on enabling licensing of technology from patentees to technology users has the potential to provide the full basis for the patent system, as well as allow for robust, consensus-building utilitarian justification for it. ${ }^{53}$ In particular, this framing puts heavy emphasis on ex ante licensing-actual technology transfer-and has little room for ex

${ }^{52}$ See Paul J. Heald, A Transaction Costs Theory of Patent Law, 66 OHIO ST. L.J. 473, 489 (2005) (arguing from a transaction cost perspective that "[t]he patent form enables a potential transferor to share an information asset without fear of misappropriation while assembling the complex team necessary to commercialize a new product"); Robert P. Merges, A Transactional View of Property Rights, 20 BERKELEY TECH. L.J. 1477, 1499 (2005); Paul J. Heald, Optimal Remedies for Patent Infringement: A Transactional Model, 45 HoUS. L. REV. 1165, 1174 (2008) (arguing that a transactional model "permit[s] the exposition of a model that need not rely on ex ante assumptions about optimal R\&D expenditures"); Liivak, Maturing Patent Theory, supra note 51, at 1165; Liivak, Establishing an Island of Patent Sanity, supra note 16, at 1343; Henry E. Smith, Property as Platform: Coordinating Standards for Technological Innovation, 9 J. COMPETITION L. \& ECON. 1057, 1076 (2013) ("As I will show, the modular theory of property points to a strong role for commercialization concerns to shape intellectual property."); Stephen Yelderman, Coordination-Focused Patent Policy, 96 B.U. L. REv. 1565, 1566-67 (2016).

${ }_{53}$ See Liivak, Establishing an Island of Patent Sanity, supra note 16, at 135758 (2013); Liivak, Maturing Patent Theory, supra note 51, at 1182. 
post licensing. ${ }^{54}$ Notably, ex post licensing is the domain of patent trolls and therefore this tech transfer framing provides no support for the patent troll business model. Furthermore, this framing can avoid the pathological pitfalls that have hampered the reward theory.

Before exploring these solutions in more detail, it is worth pointing out that Merges and Lemley both provide hints suggesting that this direction may suit them. Merges explores the impossibility of the regulatory incentive system and he rightly compares its informational complexity to the impossibility of "designing a perfect socialist economy." 55 This comparison surely suggests the consideration of a patent system modeled on private property and its system of exchange. That private property system does not put impossible informational demands on system design. This transactional theory is aiming to be exactly such a theory in the realm of ideas. Similarly, though he seems unwilling to admit it, ${ }^{56}$ Lemley also hints that private property-and its attendant microeconomic theories-may provide the starting point for fruitful solutions. After all, he premises much of his arguments on "the fundamental discovery that market mechanisms supplemented with some infrastructure investment and health and safety regulation generally work better than anything else in providing most goods and services." But those markets and the theories of perfect competition that he aims to protect are all predicated on a system of private property. Perhaps an analog theory for patents that rightfully recognizes the critical differences between rival and nonrival goods could be a step in the right direction. Again, I think a transactional theory of technology transfer can be such a theory.

\section{A. A Neutral Platform for Enabling Technology Transfer}

The reward theory aims to draw people to the business of inventing. Society worries that too few people will become inventors and thus, the conventional framing takes the most

${ }^{54}$ See Fed. Trade Comm'n, The Evolving IP MarketPlace: Aligning Patent NOTICE AND REMEDIES WITH COMPETITION 7-8, 31-72 (2011), https://www.ftc.gov/ sites/default/files/documents/reports/evolving-ip-marketplace-aligning-patent-noticeand-remedies-competition-report-federal-trade/110307patentreport.pdf.

55 MERGES, supra note 7 , at 3.

${ }^{56}$ See Lemley, supra note 3 , at 1345.

${ }^{57}$ Id. at 1330. 
direct approach to getting people to become inventors. Yet, as explained above, the direct approach leads to numerous unresolvable problems. The alternative technology transfer regime takes a less direct approach. It does not explicitly aim to make inventing a profitable activity for all inventors. Rather, it simply provides the legal platform upon which inventors can sell their technologies to users. As a platform, it is largely agnostic about how many people should take advantage of marketing inventions to users. In other words, it does not aim to induce. Accordingly, such a system need not know beforehand-or even later to optimize it-how much inventive activity is optimal. Potential inventors and potential technology users will themselves decide when to use this platform.

\section{B. Exclusivity Not Exclusion}

As a patent system that emerges from the Patent and Copyright clause, the mode of "promoting progress" is limited to "exclusive rights." $"$ In the reward theory, those rights are designed to exclude others from access. For some, the right to exclude is tied directly to the constitutional mandate. ${ }^{59}$ And certainly the right to exclude is seen by many as the fundamental defining characteristic of property systems. ${ }^{60}$ Yet, other property scholars have offered an alternative understanding. Property should focus on exclusivity rather than exclusion. ${ }^{61}$ For intellectual property that means focusing not on excluding others as is inherent in the reward framing, but instead to understand the intellectual property owner as holding an exclusive position in regards to the work in question. For the technology transfer framing of the patent system, this exclusive position of the patent owner should be understood as the right-and obligation-to be the exclusive supplier of the patented invention to users of the invention.

58 Livak, Maturing Patent Theory, supra note 51, at 1180, 1185.

59 See Roger Milgrim, An Independent Invention Defense to Patent Infringement: The Academy Talking to Itself: Should Anyone Listen?, 90 J. PAT. \& TRADEMARK OFF. SOC'Y 295, 297-98 (2008).

60 See Thomas W. Merrill, Property and the Right To Exclude, 77 NEB. L. REV. 730,730 (1998).

61 Larissa Katz, Exclusion and Exclusivity in Property Law, 58 U. TORONTO L.J. 275,275 (2008). 
C. Focus on Value of Use of Invention, Not Value of Exclusion

Inventors will devote scarce resources to inventing when they believe there is a large enough market for the invention that the cumulative ex ante licensing revenue exceeds the opportunity costs of those consumed scarce resources. In other words, people will invent when it is their best option. Likewise, technology users will come to this market to get the new technology where the private value of using the new technology exceeds the value of the other things that could be bought with the asked-for licensing fee. The utilitarian justification is straightforward. If an inventor can stay in business by selling his or her inventions to others, then society concurs that the creation of the technology is the best use of scarce resources.

\section{CONCLUSION}

The current reward framing for the patent system has resisted all attempts to either confirm or to refute the benefits of the system. Yet that should not surprise us. We should be surprised that we ever thought that the system could be justified at all. The reward framing has infected the patent system with pathological defects that make the system both unjustifiable and unfalsifiable. An alternate framing that focuses on ex ante technology transfer can support and explain many of the doctrinal features of the current patent system, but it can do so while avoiding the pathologies that plague today's patent theory. 